\title{
A DISTRIBUTED FRAMEWORK FOR COLLABORATIVE SUPPLY NETWORK INTEGRATION
}

\author{
Jean-Marc Frayret ${ }^{1}$, Louis Cloutier ${ }^{1,2}$, \\ Benoît Montreuil ${ }^{1}$ and Sophie D'Amours ${ }^{1}$ \\ ${ }^{1}$ CENTOR, Université Laval, CANADA \\ ${ }^{2} A P G$ Solutions \& Technologies, CANADA \\ \{jm.frayret, louis.cloutier, benoit.montreuil, sophie.damours\}@centor.ulaval.ca
}

\begin{abstract}
This paper presents the latest developments of the NetMan generic framework for the design and operation of distributed manufacturing and supply networks. This framework enables the implementation of specific collaborative strategies, as well as the integration of distributed business processes into a seamless value creation process. This approach, described as a collaborative integration of the business-to-business (B-to-B) interactions, allows the distributed units of a network to exchange information in a coordinated manner and to collaboratively plan, control and manage day-to-day operations and contingencies in a dynamic environment.
\end{abstract}

\section{INTRODUCTION}

Collaborative supply networks are explicitly built up from distributed and autonomous or semi-autonomous business units. In such organizations, collaboration performance measures the ability of the distributed units to work together in order to deliver value to their customers in an effective and efficient manner. In this context, effective refers to the extent to which end customers' and partners' needs are met, and efficient translates how economically the network's resources are utilized and integrated when providing a given level of customer satisfaction (adapted from Neely et al. 1995). Thus, in a network context, high performance emerges from the value network integration performance.

This paper proposes an organizational and operational framework allowing distributed centers from supply networks to integrate their individual value creation processes into a seamless collaboration process.

The original version of this chapter was revised: The copyright line was incorrect. This has been corrected. The Erratum to this chapter is available at DOI: 10.1007/978-0-387-35399-9_52 


\section{PRACTICE AND RESEARCH OVERVIEW}

Two main aspects are addressed in this section. The first concerns some of the collaborative practices currently emerging in manufacturing and logistic businesses. The second concerns the research directions developed to integrate supply chains, enterprises and virtual organizations.

Collaboration, and the ways to enable it, form a wide field of study, concerning human organization research (Cohen and Mankin 1999; Tuomela 2000), as well as new information technologies development (Schrage 1990).

The aspect of collaboration, which is more specifically addressed in this paper, concerns the creation of a seamless decision making network across the entire supply chain. The need to create such an embedded decision process arises mainly from the distributed decision process inconsistency.

To illustrate this point, many authors studied the production-distribution systems dynamic, involving supplying, manufacturing, assembling, cascaded inventories and ordering procedures across the supply chain (Forester, 1961; Lee et al. 1997). The results show that independent control across the supply chain amplifies small disturbances from the market, increasing inventory levels without assuring on-time delivery. This effect (known as the bullwhip effect) is explained by the distortion of information demand across the supply chain. It can lead to tremendous inefficiencies (e.g., excessive inventories, poor service level, misguided capacity plans, ineffective transportation, missed production schedule, etc., Lee et al. 1997).

In order to prevent this from occurring, some approaches propose to create an area of collaboration between supply chain's units, better known as the boundaryless cooperation or the cross-organizational collaboration. Within this collaboration, managers interact and make joint decisions, which are proved to be more consistent within the supply network context, hence leading to better performances.

Many collaborative programs and approaches have been proposed by researchers and practitioners. Stank et al. (1999) present an empirical study of a collaborative planning approach to support automatic replenishment programs. In this approach, (the Collaborative Planning, Forecasting and Replenishment, CPFR), collaboration consists, in practice, in creating joint business plans, defining shared sales forecasts based on retail actual data, and identifying contingencies to be jointly resolved.

Stanford University and Andersen Consulting have conducted a survey of over 200 companies to study the most common collaborative programs implemented in business practices (e.g., CPFR, Vendor Managed Inventory, point-of-sales data sharing, EDI, joint product development, joint merchandizing, customized pallets, joint sales forecasting, reverse logistics). They clearly show that the most profitable companies collaborate through such programs (Cudahy and Lee 1999).

Collaboration has thus become a leitmotiv in supply chain management practices and research. To support it, many research projects on enterprise and supply chain integration have been conducted. Basically, it consists in giving each organizational unit access to information relevant to its task, in order to give it the means to understand how its actions will impact other parts of the organization, hence 
enabling it to choose alternatives that optimize the organization's goals (Shen and Norrie 1999a).

Many supply chain integration approaches have been proposed, albeit no unified ontology has been widely agreed upon (Camarinha-Matos et al. 1997). Such approaches may address several aspects, from the intra-organization integration, to inter-organization collaboration closeness and operational excellence (Morash and Clinton, 1998).

Many multi-agent approaches to supply chain and virtual enterprise integration have been proposed (e.g., Fox et al. 1993; Brugali et al. 1998; Strader et al. 1998; Shen et al. 1999; Shen and Norrie 1999b, Cloutier et al. 1999). Swaminathan et al. (1998) proposed an agent-based supply chain simulation plate-form. Finally, Khoo et al. (1998) studied the potential of agent-based approaches to automatic procurement on the web.

The approach discussed in this paper delves further into those generic concepts. It first defines a strategy to design network organizations. Then, it proposes a set of concepts to implement, through agent-based structures, the network organization's integration plat-form, describing explicitly their collaborative interactions.

\section{NETMAN ORGANIZATIONAL APPROACH}

The concepts presented here take place in a strategic organizational and operational framework introduced in Montreuil et al. (2000) and Frayret et al. (forthcoming). It can basically be described through its organizational and business-to-business (B-toB) collaboration principles.

\subsection{NetMan Organizational strategy}

The NetMan organizational paradigm formalizes global manufacturing businesses as heterarchical (Duffie 1990) responsibility-based networks (Montreuil and Lefrançois 1996) of autonomous, or semi autonomous, and interdependent business units called NetMan centers. A mission, expressed in terms of responsibility for satisfying clients' (more generally its interactors') needs (such as supplying components, providing resources, providing maintenance or logistic services, coordinating a supply network of centers, managing demand, etc.), is assigned to each of them, within which it is self-organized. Thus, in order to fulfill its mission, it can acquire new technologies or re-engineer its internal set of resources. NetMan centers are designed and geared up with customized management tools using finely granular information. They also sustain partnerships with each other to share information, make joint decisions, negotiate, and jointly resolve contingencies. 


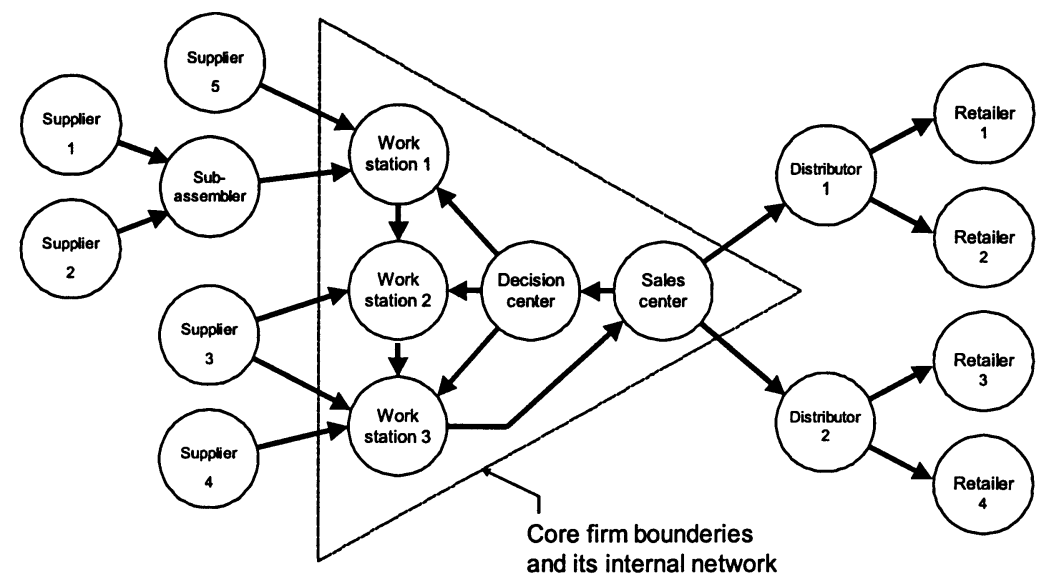

Figure 1 - Network organization structure example

Therefore, NetMan networks constitute comprehensive sets of mission-focussed centers, distributed and connected by links translating their customized partnerships. These centers may be internal specialized units of a firm (machines, workstations, departments, plants), as well as external businesses (suppliers, subcontractors, or service providers).

Figure 1 presents such a structure, described by Snow et al. (1992) as a stable network, constituted of a manufacturing core firm and its different levels of suppliers, sub-assemblers, distributors and retailers. However, NetMan networks may also be constituted from comprehensive sets of small-and-medium-sizedenterprises as well, integrated together using the same collaborative planning and operation principles.

Each NetMan center, according to its capacity and privileges, may fulfill its mission using four distinct approaches (see Figure 2): first of all, (a) it can use its business relationships with internal or external partners, or adapt those relationships to new requirements due to environmental changes or new overall or local objectives; (b) it can define new business relationships with existing NetMan centers or new external businesses, and use these relationships; (c) it can use its own internal resources (data processing capabilities, physical assets, etc.); then (d) it can have the privilege (given by its owner(s)) of creating new NetMan centers, with which it establishes partnerships to satisfy some of its needs. These four approaches allow the NetMan centers to self organize and to dynamically reconfigure their partnerships according to environmental pressures.

A strategic control approach is being developed in order to assess performance in such distributed contexts, and then to assure and maintain the consistency between the distributed manufacturing and supply strategies and objectives. 


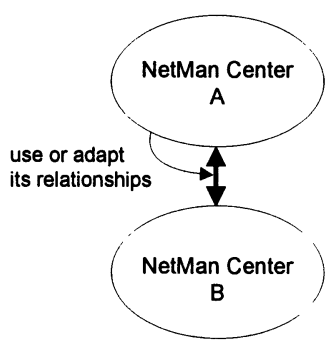

(a)

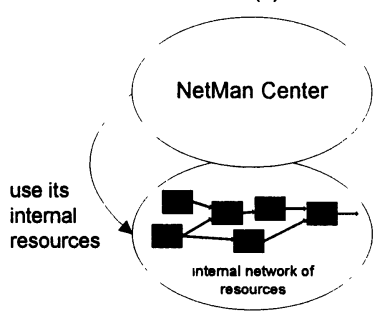

(c)

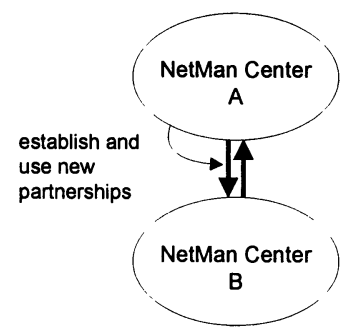

(b)

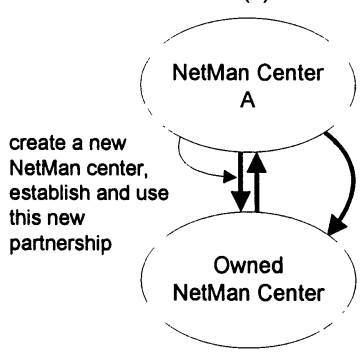

(d)

Figure 2 - Four generic strategies to fulfill a NetMan center's mission

Such network organizations can be modeled as a set of business processes, which are parts of the clients' needs fulfillment process, and a set of interacting actors collaborating to carry them out. NetMan formalizes business processes within each center, moving the decision making process closer to the source of information. Therefore the collaboration and transactions modeling issues are highlighted to allow partners to finely tune their interactions in order to gain efficiency and effectiveness from a better B-to-B integration.

Table 1 : Comparison of design and operational features. Extension of Tharumarajah et al. (1996)

\begin{tabular}{|c|l|l|l|l|}
\hline $\begin{array}{c}\text { System } \\
\text { parameter }\end{array}$ & \multicolumn{1}{|c|}{$\begin{array}{c}\text { Bionic } \\
\text { manufacturing }\end{array}$} & Fractal factory & $\begin{array}{c}\text { Holonic } \\
\text { manufacturing } \\
\text { systems }\end{array}$ & NetMan strategic approach \\
\hline $\begin{array}{c}\text { Definition of } \\
\text { unit }\end{array}$ & $\begin{array}{l}\text { Cells: multi- } \\
\text { operation and } \\
\text { defined through } \\
\text { genesis }\end{array}$ & $\begin{array}{l}\text { Fractal: corporate } \\
\text { service entity, multi- } \\
\text { dimensional (incl. } \\
\text { Technical, human } \\
\text { and cultural) }\end{array}$ & $\begin{array}{l}\text { Functional and } \\
\text { predefined }\end{array}$ & $\begin{array}{l}\text { NetMan centers: } \\
\text { Responsibility-oriented, } \\
\text { defined in terms of partners' } \\
\text { business needs satisfaction }\end{array}$ \\
\hline $\begin{array}{c}\text { Definition of } \\
\text { group }\end{array}$ & $\begin{array}{l}\text { Organs: cell } \\
\text { division to } \\
\text { support needed } \\
\text { functionality, } \\
\text { more dynamic }\end{array}$ & $\begin{array}{l}\text { Predefined and } \\
\text { recursive as similar } \\
\text { service fractals, also } \\
\text { dynamic regrouping }\end{array}$ & $\begin{array}{l}\text { Predefined set of } \\
\text { holons in holarchy } \\
\text { to support specific } \\
\text { functions }\end{array}$ & $\begin{array}{l}\text { NetMan networks: } \\
\text { customized business- } \\
\text { oriented network of } \\
\text { autonomous and } \\
\text { interdependent collaborating } \\
\text { NetMan centers }\end{array}$ \\
\hline $\begin{array}{c}\text { Autonomy } \\
\text { of unit }\end{array}$ & $\begin{array}{l}\text { High, cells able } \\
\text { to define } \\
\text { operations in }\end{array}$ & $\begin{array}{l}\text { High, setting of } \\
\text { individual goals and } \\
\text { adaptability through }\end{array}$ & $\begin{array}{l}\text { High, } \\
\text { independence in } \\
\text { negotiation and }\end{array}$ & $\begin{array}{l}\text { High, independence in } \\
\text { negotiation and cooperation } \\
\text { to set goals and tasks, in }\end{array}$ \\
\hline
\end{tabular}




\begin{tabular}{|c|c|c|c|c|}
\hline & $\begin{array}{l}\text { response to } \\
\text { changes in } \\
\text { operating } \\
\text { environment }\end{array}$ & vitality & $\begin{array}{l}\text { cooperation to set } \\
\text { goals and tasks, } \\
\text { limited by fixed } \\
\text { set of rules }\end{array}$ & $\begin{array}{l}\text { accord with the business } \\
\text { parent fundamental needs } \\
\text { and the partnership } \\
\text { agreements }\end{array}$ \\
\hline $\begin{array}{c}\text { Autonomy } \\
\text { of group }\end{array}$ & $\begin{array}{l}\text { Predefined } \\
\text { functions of } \\
\text { organs through } \\
\text { genesis and } \\
\text { operational } \\
\text { autonomy }\end{array}$ & $\begin{array}{l}\text { Inheritance of self- } \\
\text { similar fractals and } \\
\text { autonomy of goals; } \\
\text { also dynamic } \\
\text { restructuring }\end{array}$ & $\begin{array}{l}\text { Flexible strategies } \\
\text { subject to fixed } \\
\text { set of rules with } \\
\text { stable } \\
\text { intermediate } \\
\text { forms }\end{array}$ & $\begin{array}{l}\text { Flexible and independent } \\
\text { reconfiguration with respect } \\
\text { to the owner/ownee } \\
\text { agreements }\end{array}$ \\
\hline $\begin{array}{l}\text { Hierarchical } \\
\text { coordination }\end{array}$ & $\begin{array}{l}\text { Top-down as } \\
\text { task } \\
\text { specification } \\
\text { and bottom-up } \\
\text { decisions }\end{array}$ & $\begin{array}{l}\text { Top-down and } \\
\text { bottom-up as } \\
\text { concurrent and } \\
\text { iterative goal } \\
\text { coordination }\end{array}$ & $\begin{array}{l}\text { Top-down as } \\
\text { incomplete plans } \\
\text { and bottom-up as } \\
\text { decisions and } \\
\text { performances }\end{array}$ & $\begin{array}{l}\text { 1: owner/ownee fundamental } \\
\text { needs and performance } \\
\text { measurements mutual } \\
\text { expression } \\
2: \text { Client/provider needs and } \\
\text { offers expression and } \\
\text { fulfillment }\end{array}$ \\
\hline $\begin{array}{c}\text { Lateral } \\
\text { coordination }\end{array}$ & $\begin{array}{l}\text { Indirect through } \\
\text { shared cell } \\
\text { environment } \\
\text { and enzymatic } \\
\text { operator } \\
\text { (coordinator) }\end{array}$ & $\begin{array}{l}\text { Network of } \\
\text { communication and } \\
\text { cooperation, and } \\
\text { fractal navigation to } \\
\text { assess situation }\end{array}$ & $\begin{array}{l}\text { Communication } \\
\text { and cooperation } \\
\text { among holons } \\
\text { (holarchies as } \\
\text { holons) }\end{array}$ & $\begin{array}{l}\text { Direct communication and } \\
\text { cooperation, using an explicit } \\
\text { coordination framework } \\
\text { between interacting NetMan } \\
\text { centers }\end{array}$ \\
\hline $\begin{array}{l}\text { Planning } \\
\text { and control }\end{array}$ & $\begin{array}{l}\text { Minimal: mostly } \\
\text { reaction to } \\
\text { emerging } \\
\text { situations; } \\
\text { concurrent }\end{array}$ & $\begin{array}{l}\text { Continuous as goal } \\
\text { revisions between } \\
\text { parent-child fractals }\end{array}$ & $\begin{array}{l}\text { Some planning at } \\
\text { higher level } \\
\text { (holarchy), mostly } \\
\text { dynamic and } \\
\text { concurrent } \\
\text { through } \\
\text { communication }\end{array}$ & $\begin{array}{l}\text { Distributed and concurrent; } \\
\text { each NetMan center plans } \\
\text { and gontrols its own internal } \\
\text { network of fesources, } \\
\text { according to its agreements } \\
\text { and commitments with others } \\
\text { NetMan centers }\end{array}$ \\
\hline
\end{tabular}

From a comparative point-of-view, the NetMan foundations are quite similar to others existing manufacturing concepts involving distributed and autonomous units (e.g., bionic, fractal and holonic manufacturing). A study provided in Tharumarajah et al. (1996) is used here as a starting point to carry out this comparison. Table 1 summarizes the design and operational features' comparison of the four approaches.

Thus, NetMan appears to share some features with the three mentioned approaches, even though NetMan networks are designed from a responsibility decomposition of systems rather than a functional decomposition as in holonic manufacturing.

The scope of NetMan center functionalities is then less restrictive and appears to be more dynamic and reconfigurable, as long as it respects its owner/ownee agreements. From an operational point-of-view, NetMan centers plan and control their own network of resources, with respect to and according to its agreements with others NetMan centers. As in other distributed approaches, these features lead to almost no hierarchic control over the centers. NetMan centers are explicitly selfmanaged within their operations and design, as long as they respect their agreements and fulfill their mission and the responsibility assigned to them by their owner centers. Finally, NetMan explicitly aims to naturally integrate supply networks, modeling them as responsibility-based networks within a collaboration framework.

\subsection{NetMan B-to-B Collaboration principles}

Collaboration in manufacturing and supply networks may arise in practice in many cases, such as: (a) when many business entities work together to achieve a collective 
goal (when none of them have sufficient capacity to achieve this goal); or (b) to achieve their own goals (when these goals are strategically aligned to avoid contradictions); or (c) when these entities share one or many resources (when none of them have sufficient resources to achieve their own goal efficiently); or (d) to share the benefit emerging from a mutual agreement (coalition and coopetition).

In the context of this paper, the three first kinds of collaboration are addressed. Thus, in order to satisfy their clients' needs, the networks of autonomous and semiautonomous centers rely on a well designed and planned collaborative structure. This structure is implemented practically through the establishment of rules-of-thegame between centers, translating their explicit interactions strategies. Thus, from a collaboration perspective, centers use a set of predefined conventions and agreements to mutually interact. These conventions and agreements concern the nature of centers' interactions and the way they must be driven (Cloutier et al. submitted). As none of them has the capacity to satisfy alone the clients' needs, they collectively carry out the clients' need fulfillment process. To do so, they express needs to each other, generate offers, and mutually commit to perform operations.

In NetMan, a need is considered as one of the basic components involved in centers' interactions. They have different origins. First, they can concern the explicit decomposition of the clients' need and its fulfillment process (e.g., a sub-assembly component, a set of processes to carry out, a resource, etc.). Such needs also include emergency requests to solve contingencies. The second origin concerns the distributed structure of NetMan organizations and their coordination requirements. Therefore, to make sure the distributed centers perform well together and mutually adjust their operations and adapt to each other's constraints, needs must also be expressed (Johanson and Mattsson 1987). For example, such a need may concern capacity loading forecasts or logistic information to coordinate centers' activities. Thus, needs can be expressed directly because of the centers' limited capacity to satisfy their clients' needs, or during operations when a contingency occurs. Then, needs may also be expressed because of the collaboration process involved in coordinating centers' activities.

In NetMan, to each expressed need corresponds an offer, which is a proposition from the provider center to satisfy the need. According to the offer's relevance in satisfying the need, the initial need may be either adjusted and expressed again, or confirmed by the client, which then lead to a mutual commitment.

NetMan promotes the use of suppliers' models, which provide each NetMan center with a partial view of its interactor centers, in order to let it plan its internal resources with respect to its multiple dependencies with them. Such models represent the abstraction of a provider's ability to satisfy its client's needs. Therefore, a center that knows its providers' model can accelerate its own offer expression process as it knows its providers' ability to collaborate to satisfy its needs. In NetMan, needs are expressed when the providers' capacity to satisfy them is undetermined, or when needs are actually confirmed, leading to a mutual commitment of both client and provider centers.

These concepts are the basic foundations of a distributed planning approach, formalizing centers' interactions rather than letting the planning and the scheduling of all the distributed activities be an emerging process. 


\section{NETMAN INTEGRATION PLATE-FORM}

NetMan proposes an agent-based integration plate-form, modeling NetMan centers as a set of software agents (e.g., e-business agents, planning agents, operations control agents (Cloutier et al. 2000)), using the CAT coordination framework between interacting center's e-business agents. CAT (for Convention, Agreement and Transaction) is a coordination framework that aims to provide a flexible and generic tool to support activities coordination in networked manufacturing (Cloutier, 1999). Moreover, Cloutier et al. (submitted) present a generic framework describing how to implement specific collaboration strategies into an agent-based business approach.

To do so, collaborative strategies are translated into agreements and conventions, using conversation protocols and contingency rules shared by agents, in order to let them commit later to perform coordinated operations. In the NetMan implemented prototype, agreements, and conventions are formalized with XML (Extensible Markup Language) as the coordination structure representation language to automate conversations between centers' e-business agents. Then, messages are formalized using FIPA/ACL (FIPA 1997) as the agent communication language.

\subsection{Collaborative programs implementation}

The NetMan plate-form approach aims to provide a natural way to implement some of the collaborative programs mentioned earlier. Thereby, as long as such programs can be formalized into patterns of information modeling and sharing, negotiation and/or joint decision making, it is possible to define specific conversation protocols, contingency rules and internal software agents that can handle centers' interactions, as well as their implication on the centers' internal business processes.

Figure 3 presents an example of integrated supply network, consisting of a provider, a manufacturer, a distribution center and two retailers, embedded in a Bto-B integration plate-form. This plate-form helps these centers to exchange relevant information, expanding their business context bounded knowledge, in order to allow them to make consistent decisions. It also helps them to aggregate and generate forecast and capacity models, decompose and express their needs, generate their offers, plan and schedule their own resources, detect contingency situations and trigger their solutions within and outside centers' boundaries.

In this example, the two retailers send and periodically update the distribution center their models consisting of their actual retail data, their promotion calendars, and their inventory levels. Then, according to these models, the distribution center aggregates the data and generates accurate forecasts it then shares with the retailers and the manufacturer. Thereby, the latter decomposes those forecasts, plans and then shares its future needs with the provider. In order to make sure that the manufacturer's partners (e.g., the provider and the distribution center) will be able to handle its future capacity deployment, it sends them a model of this forecasted capacity deployment. 


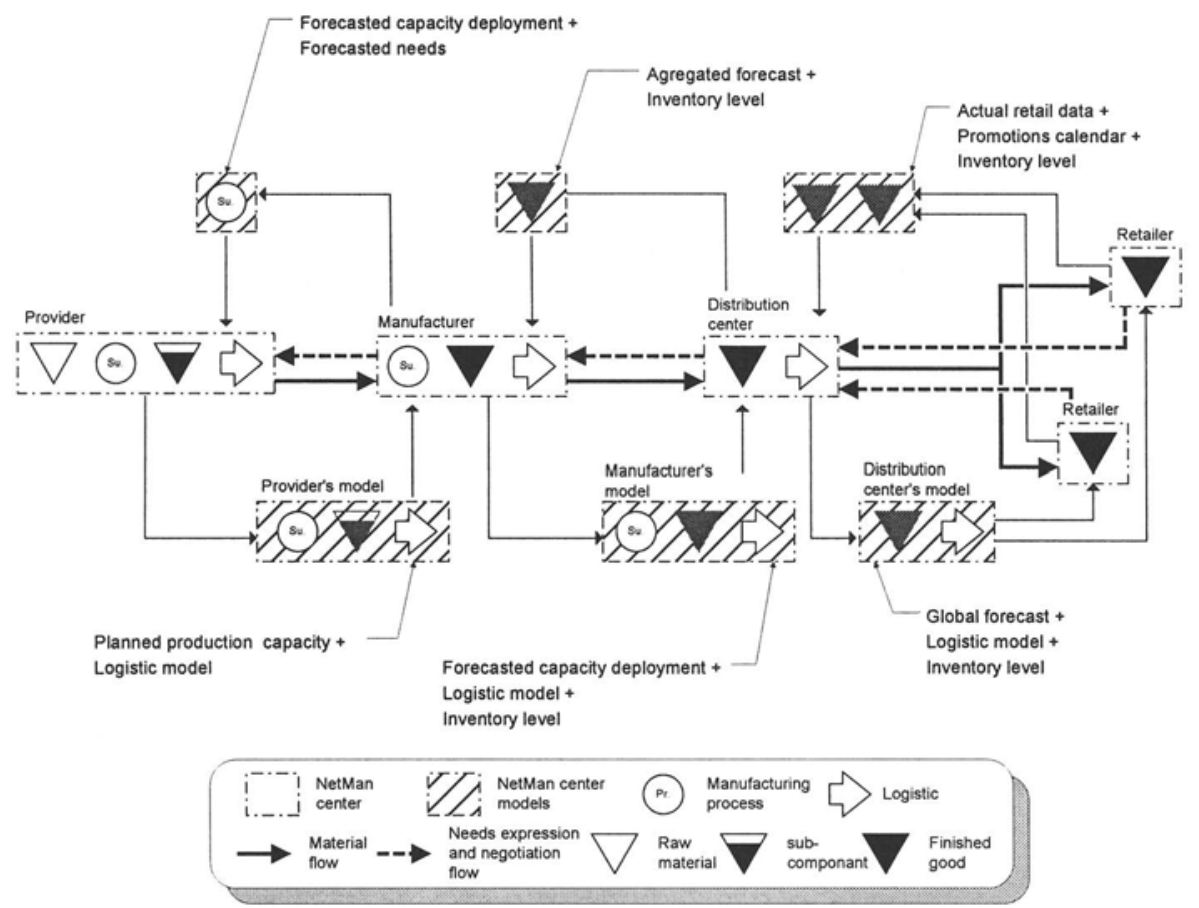

Figure 3 - Integrated supply network example

The day-to-day interaction between centers' e-business agents concerns their center's needs and offers expression, as well as the joint contingency management. To do so, these agents use customized conversation and negotiation protocols, parts of the customized centers' agreements that allows them to organize simple and complex information exchanges into structured conversations that aim to propose solutions. Embedded in these conversations, centers' other internal agents may plan and schedule, generate other needs to express to their provider, and of course ask for the help of a human manager when they are not able to find a solution by themselves. These processes are tightly linked to the internal architecture of the information system of the center, which is detailed in Cloutier et al. (2000).

\section{CONCLUSION}

This paper proposes an integration plate-form for networked organizations, based on B-to-B collaborative integration. First, it consists in mapping (and eventually reorganizing) the supply network structure onto a responsibility-based network of independent mission-focused centers. Then, collaborative relationship are explicitly defined between these centers, in order to allow the information and decision system to automatically handle the distributed planning and operations. These collaborative 
programs are thus translated into business rules-of-the-game, which in turn are translated into agreements and conventions shared by centers' e-business agents.

In this approach, e-business may be defined as the merging of highly dedicated decision support tools with the Internet technology, in order to create a seamless clients' need fulfillment process across distributed supply networks. E-business is thus fundamentally linked to inter-connecting firms' information systems, enabling them to plan and manage their interdependent manufacturing and logistic operations.

An important issue in this approach concerns the implementation of efficient rules-of-the-game between firms or centers, which drive their interactions and lead to the overall supply network performance. Research is being carried out in this direction at the CENTOR research center from the Université Laval (Québec, Canada). This research concerns the study and analysis of collaborative interactions between manufacturing and, more generally, business centers that can enable supply networks to create leading competitive advantages.

\section{REFERENCES}

1. Brugali D, Menga G, Galarraga G. "Inter-Company Supply Chain Integration via Mobile Agent". In The Globalization of Manufacturing in the Digital Communications Era of the 21st Century: Innovation, Agility, and the Virtual Enterprise, G. Jacucci, GJ Olling, K Preiss, MJ Wozny, eds., Kluwer Academic Publishers, 1998.

2. Camarinha-Matos LM, Afsarmanesh H, Garita C, Lima C. "Towards an architecture for virtual enterprises". In Proceedings of the $2^{\text {nd }}$ World Congress on Intelligent Manufacturing Processes \& Systems, Budapest, Hungary, 1997.

3. Cloutier L. Une approche multi-agents par conventions et contrats pour la coordination de l'entreprise réseau manufacturière. Ph.D thesis, Université d'Aix-Marseille III, France, 1999.

4. Cloutier, L, Espinasse, B, Lefrançois, P. "Networked Enterprise Integration: an Agent-Based Coordination Framework". In Proceedings of The 14th World Congress of International Federation of Automatic Control (IFAC'99), Special session on Enterprise Integration, 5-9, Beijing, China, july, 1999.

5. Cloutier L, Frayret JM, D'Amours S, Espinasse B, Montreuil B. A Commitment-Oriented Framework to Networked Manufacturing Co-ordination. Submitted to International Journal of Computer Integrated Manufacturing.

6. Cloutier L, Frayret JM, D'Amours S, Montreuil B. "The NetMan Multi-agent Architecture for EBusiness in Network Organizations". In proceedings of PRO-VE 2000 - 2nd IFIP Working Conference on Infrastructures for Virtual Enterprises, Florianopolis, SC, Brazil, 2000.

7. Cohen SG, Mankin D. "Collaboration in the virtual organization". In Trends in Organizational Behavior, CI Cooper, DM Rousseau, Eds., John Wiley \& Sons, 1999, 105-120.

8. Cudahy GC, Lee HL. "Logistics Collaboration: What Types of Collaboration Create Value?", presented at the Council of Logistics Management Annual Conference, October 17-20, Toronto, Ontario, Canada, 1999.

9. Duffie N. Synthesis of heterarchical manufacturing systems. Computers in industry, 1990, 14(1/3), 167-174.

10. FIPA (Foundation For Intelligent Physical Agents). FIPA 07 Specification Part 2 - Agent Communication Language, 1997.

11. Forrester J. Industrial Dynamics. New York: MIT press, and John Wiley and Sons, 1961.

12. Fox MS, Chionglo JF, Barbuceanu, M. The Integrated Supply Chain Management System, Internal Report, Dept. of Industrial Engineering, Univ. of Toronto, 1993.

13. Frayret JM, D'Amours S, Montreuil B, Cloutier L. forthcoming. A Network Approach to Operate Agile Manufacturing Systems, International Journal of Production Economics.

14. Johanson J, Mattsson LG. Interorganizational Relations in Industrial Systems: A Network Approach Compared with the Transaction-Cost Approach, International Studies of Management \& Organization, 1987, 17, 34-48. 
15. Khoo LP, Tor SB, Lee, SSG. The Potential of Intelligent Software Agents in the World Wide Web in Automating Part Procurement. International Journal of Purchasing and Material Management, 1998, 34(1), 46-52.

16. Lee HL, Padmanabhan V, Whang S. The bullwhip effect in supply chains. Sloan Management Review, 1997a, 38(3), 93-102.

17. Neely A, Gregory M, Platts K. Performance measurement systems design A literature review and research agenda. International Journal of Operations \& Production Management, 1995, 15(4), 80-116.

18. Montreuil B, Frayret JM, D'Amours S. A Strategic Framework for Networked Manufacturing. Computers in industry, 2000, 42(2-3), 299-317.

19. Montreuil B, Lefrançois P. "Organizing Factories as Responsibility Networks". In Progress in Material Handling, RJ Graves, LF McGinnis, DJ Medeiros, RE Ward, MR Wilhelm, eds., M.H.I, Braum-Brumfield, United States, 1996, 375-411.

20. Morash EA, Clinton SR. Supply chain integration: Customer value through collaboraive closeness versus opertional excellence. Journal of Marketing Theory and Practice, 1998, 6(4), 104-120.

21. Shen W, Norrie DH. Agent-Based Systems for Intelligent Manufacturing: A State-of-the-Art Survey. Knowledge and Information Systems, An International Journal, 1(2), 129-156, 1999a.

22. Shen W, Norrie DH. "Implementing Internet Enabled Virtual Enterprises using Collaborative Agents". in proceedings of PRO-VE 1999 - 1st IFIP Working Conference on Infrastructures for Virtual Enterprises, Porto, Portugal, 1999b

23. Shen W, Ulieru M, Norrie DH, Kremer R. "Implementing the Internet Enabled Supply Chain through a Collaborative Agent System". In proceeding of Agents'99 Workshop on Agent Based Decision-Support for Managing the Internet-Enabled Supply-Chain, Seattle, USA, 1999.

24. Schrage M. Shared Minds The New Technologies of Collaboration. Random House, N.-Y, 1990.

25. Snow CC, Miles RE, Coleman HJJr. Managing $21^{\text {st }}$ Century Network Organizations. Organizational Dynamics, 1992, 20(3), 5-20.

26. Stank TP, Daugherty PJ, Autry CW. Collaborative planning: supporting automatic replenishment programs. Supply Chain Management, 1999, 4(2), 75-85.

27. Strader TJ, Lin FR, Shaw MJ. Information infrastructure for electronic virtual organization management. Decision Support Systems, 1998, 23, 75-94.

28. Swaminathan JM, Smith SF, Sadeh NM. Modeling supply chain dynamics: A multi-agent approach. Decision Sciences, 1998, 29(3), 607-632

29. Tharumarajah A, Wells AJ, Nemes L. Comparison of the bionic, fractal and holonic manufacturing systems concepts. International Journal of Computer Integrated Manufacturing, 1996, 9(3), 217 226.

30. Tuomela R. Cooperation-A Philosophical Study. Kluwer Academic Publishers, 2000. 